\title{
Posisi matahari pada saat ekuinoks, summer solstice, dan winter solstice di observatorium ilmu falak Universitas Muhammadiyah Sumatera Utara
}

\author{
Abu Yazid Raisal \\ Observatorium Ilmu Falak, Universitas Muhammadiyah Sumatera Utara, Indonesia \\ Surat-e: abuyazidraisal@gmail.com \\ Hariyadi Putraga \\ Observatorium Ilmu Falak, Universitas Muhammadiyah Sumatera Utara, Indonesia \\ Surat-e: hariyadiputraga @gmail.com \\ Muhammad Hidayat \\ Observatorium Ilmu Falak, Universitas Muhammadiyah Sumatera Utara, Indonesia \\ Surat-e: dayatc4@gmail.com

\section{Rizkiyan Hadi} \\ Observatorium Ilmu Falak, Universitas Muhammadiyah Sumatera Utara, Indonesia \\ Surat-e: rizkiyanhadi8897@gmail.com
}

\begin{abstract}
Abstrak. Selama satu tahun, Matahari tidak selalu berada di daerah khatulistiwa, namun terkadang berada di daerah utara khatulistiwa serta daerah selatan khatulistiwa. Kedudukan Matahari di khatulistiwa disebut ekuinoks, kedudukan Matahari saat berada di titik terjauh di utara dari khatulistiwa disebut solstis musim panas (summer solstice), kedudukan Matahari saat berada di titik terjauh di selatan dari khatulistiwa disebut solstis musim dingin (winter solstice). Matahari di Observatorium Ilmu Falak Universitas Muhammadiyah Sumatera Utara menunjukkan posisi yang berbeda saat ekuinoks, summer soltice, dan winter solstice. Matahari terbit di arah timur dan terbenam di arah barat hanya terjadi pada saat ekuinoks. Meskipun saat ekuinoks, namun Matahari tidak dapat menunjukk arah timur dan barat sepanjang hari. Hal ini disebabkan pergerakan Matahari tidak tegak lurus terhadap horizon melainkan miring sesuai dengan lintang tempat.
\end{abstract}

Kata kunci: summer sosltice, winter sosltice, ekuinoks

\begin{abstract}
During one year, the Sun is not always in the equator, but sometimes it is in the north of the equator and the south of the equator. The position of the Sun at the equator is called the equinox, the position of the Sun when it is at its farthest point north of the equator is called the summer solstice, the position of the Sun when it is at the farthest point south of the equator is called the winter solstice. The Sun at Obervatorium Ilmu Falak Universitas Muhammadiyah Sumatera Utara shows a different position during the equinox, summer solstice, and winter solstice. The sun rises in the east and sets in the west only at the equinox. Even at the equinox, the Sun can't show east and west all day. This is due to the movement of the Sun not perpendicular to the horizon but tilted in accordance with the latitude of the place.
\end{abstract}

Keywords: summer sosltice, winter sosltice, equinox

\section{Pendahuluan}

Kebanyakan orang selalu mengatakan bahwa Matahari terbit di timur dan terbenam di barat. Ungkapan Matahari terbit dan Matahari terbenam secara tidak langsung mengatakan bahwa Matahari bergerak naik ke atas horizon Bumi di arah timur kemudian turun ke bawah horizon Bumi di arah barat. Namun, sebenarnya bukan Matahari yang bergerak melainkan Bumi. Selain itu Matahari terbit dan terbenam seringkali menjadi 

acuan masyarakat dalam menentukan arah, misalnya arah kiblat. Penggunaan matahari terbit dan terbenam dalam menentukan arah tidak dapat menjadi acuan yang tepat dikarenakan matahari tidak selalu terbit tepat di timur dan terbenam tepat di barat. Fenomena Matahari terlihat terbit dan terbenam tidak selalu tepat di timur dan barat diakibatkan oleh rotasi dan revolusi Bumi. Rotasi dan revolusi Bumi juga berpengaruh terhadap waktu salat dan jumlah intensitas cahaya yang diterima oleh panel surya [1][2].

Rotasi adalah perputaran Bumi terhadap sumbunya dari arah barat ke timur seperti terlihat pada gambar 1. Periode rotasi bumi adalah 23 jam 56 menit (hari sideris). Manusia memiliki keterbatasan untuk melihat fenomena rotasi Bumi secara langsung namun akibat dari rotasi Bumi tersebut dapat dirasakan [3]. Gerak rotasi mengakibatkan terjadinya perubahan siang dan malam, perbedaan waktu di daerah-daerah, dan terjadinya gerakan semu harian pada benda langit [4]. Selain itu rotasi Bumi juga mengakibatkan bentuk Bumi menjadi pepat sehingga terjadi perbedaan gravitasi di permukaan Bumi.

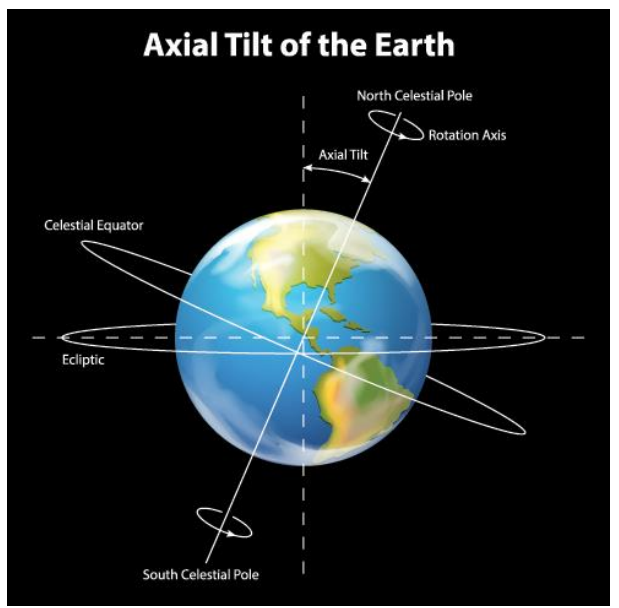

Gambar 1. Sumbu rotasi Bumi (https://climate.nasa.gov)

Selain melakukan rotasi, Bumi juga mengelilingi Matahari sebagai pusat tata surya atau yang lebih dikenal dengan revolusi Bumi. Bumi mengelilingi Matahari dalam bidang orbit yang disebut ekliptika [5]. Periode revolusi Bumi adalah 365,25 hari (satu tahun Bumi). Bumi bergerak dalam orbit yang berbentuk elips dengan Matahari berada di salah satu titik fokusnya. Hal ini menyebabkan jarak antara Bumi dan Matahari akan berubah selama ketika Bumi mengelilingi Matahari seperti terlihat pada gambar 2. Saat Bumi berada pada jarak terdekat dengan Matahari disebut perihelion. Saat Bumi berada pada jarak terjauh dari Matahari disebut aphelion.

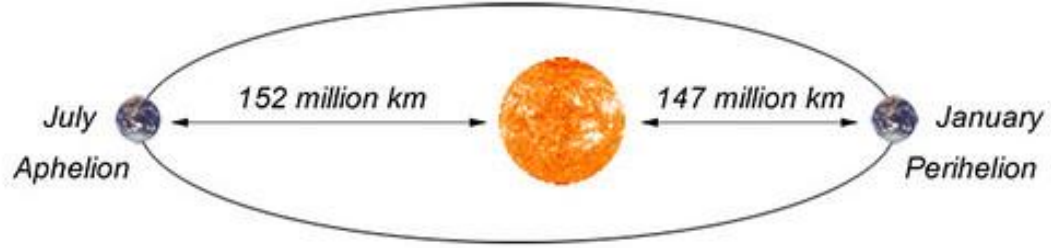

Not to scale

Gambar 2. Orbit bumi berbentuk elips (http://www.infoastronomy.org)

Ketika Bumi sengelilingi Matahari, Bumi melakukan rotasi tidak tegak lurus terhadap bidang ekliptika melainkan miring sebesar $23,5^{\circ}$ yang menyebabkan adanya perubahan musim di permukaan Bumi [6]. Selain itu juga menyebabkan terjadinya perbedaan panjang siang dan malam dan menyebabkan adanya gerak semu tahunan Matahari.

Sepanjang tahun Matahari tidak selalu berada di daerah khatulistiwa, namun terkadang berada di daerah utara khatulistiwa serta daerah selatan khatulistiwa. Peristiwa ini dikenal dengan gerakan semu tahunan Matahari. Gerakan semu tahunan Matahari dibatasi oleh garis lintang 23,5 $5^{\circ} \mathrm{U}$ yang disebut tropis Cancer atau garis balik utara dan lintang $23,5^{\circ} \mathrm{S}$ yang disebut tropis Capricorn atau garis balik selatan. Kedudukan Matahari 
di khatulistiwa disebut ekuinoks, ekuinoks terjadi dua kali selama Bumi mengelilingi Matahari yaitu pada tanggal 21 Maret disebut ekuinoks musim semi dan 23 September disebut ekuinoks musim gugur untuk belahan Bumi utara. Kedudukan Matahari pada 23,5 $5^{\circ}$ LU terjadi pada tanggal 21 Juni disebut solstis musim panas (summer solstice). Ketika solstis musim panas, Matahari mencapai titik terjauh di utara dari khatulistiwa. Kududukan Matahari pada 23,5 LS terjadi pada tanggal 22 Desember disebut solstis musim dingin (winter solstice). Ketika soltstis musim dingin, Matahari mencapai titik terjauh di selatan dari khatulistiwa [7]. Ekuinoks dan solstis tidak selalu terjadi pada waktu dan posisi yang persis sama disebabkan nilai kemiringan ekuator langit terhadap ekliptika yang bervariasi [8].

Untuk menentukan posisi Matahari terhadap Bumi dapat dilakukan dengan berbagai cara. Salah satunya adalah menggunakan tata koordinat horizon. Tata koordinat horizon merupakan tata koordinat yang paling sederhana dan paling mudah dipahami. Namun penggunaan tata koordinat ini sangat terbatas, yaitu hanya dapat menyatakan posisi benda langit pada satu saat tertentu, untuk saat yang berbeda tata koordinat ini tidak dapat memberikan hubungan yang mudah dengan posisi benda langit sebelumnya. Karena rotasi bumi, koordinat horizon benda langit yang ditinjau dari suatu tempat akan selalu berubah setiap saat [9]. Tata koordinat horizon membagi bola bumi menjadi dua bagian yaitu bagian atas yang mana letak benda-benda langit dapat dilihat dan bagian bawah yang mana benda-benda langit tidak tampak [10].

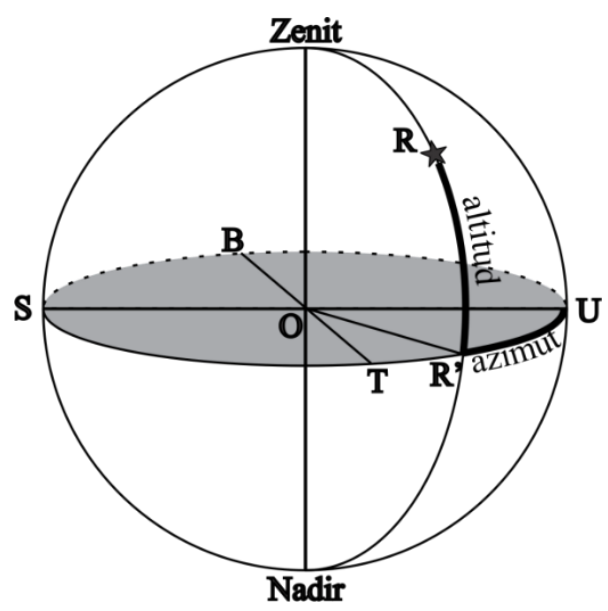

Gambar 3. Tata koordinat horizon

Dalam sistem koordinat horizon, kedudukan benda langit dinyatakan dengan oleh dua koordinat yaitu altitud dan azimut. Nilai altitud dihitung dari $0^{\circ}$ (horizon) sampai $90^{\circ}$ (zenit). Pada saat matahari terbit atau matahari terbenam nilai sudut altitud adalah $0^{\circ}$. Nilai maksimal sudut altitud adalah $90^{\circ}$ ketika posisi matahari tepat diatas kepala. Sudut azimut matahari adalah posisi sudut proyeksi Matahari di horizon diukur dari arah utara bumi searah dengan jarum jam. Nilai sudut azimut matahari $0^{\circ}$ di arah utara, $90^{\circ}$ di arah timur, $180^{\circ}$ di arah selatan, dan $270^{\circ}$ di arah barat [11].

Pembelajaran pergerakan Matahari pada bola langit merupakan salah satu dari materi astronomi. Astronomi dan IPA/Fisika merupakan materi pelajaran di SMP/SMA yang terpadu secara integral, dimana konsep-konsep astronomi melibatkan konsep-konsep fisika. Hal ini pula yang menjadi acuan dalam kurikulum, materi astronomi menjadi bagian dari mata pelajaran fisika, sehingga pengajar astronomi di SMP/SMA umumnya adalah guru IPA/Fisika [12]. Astronomi merupakan salah satu cabang yang diperlombakan dalam OSN namun hanya segelintir peserta didik yang dapat berkompetisi dengan baik. Bahkan banyak sekolah yang tidak mengetahui bahwa astronomi diperlombakan dalam OSN. Ada kesenjangan dalam pengetahuan, skill, dan kesempatan berkompetisi dalam pendidikan astronomi di Indonesia terutama di SMA [13]. Penelitian ini dilakukan untuk memverifikasi posisi Matahari saat ekuinoks, summer solstice, dan winter solstice di Observatorium Ilmu Falak Universitas Muhammadiyah Sumatera Utara. Penelitian ini diharapkan dapat membantu para guru dalam menjelaskan fenomena astronomi sehari-hari dan membuat praktikum sederhana dimanapun dengan cara yang mudah. 


\section{Metode Penelitian}

Penelitian ini dilakukan di Observatorium Ilmu Falak Universitas Muhammadiyah Sumatera Utara (OIF UMSU) yang terletak di lantai 7 gedung pascasarjana Universitas Muhammadiyah Sumatera Utara dengan titik koordinat $3^{\circ} 34^{\prime} \mathrm{LU}$ dan $98^{\circ} 43^{\prime}$ BT. Pengambilan data akan dilakukan dengan cara memotret posisi Matahari pada waktu dan tempat yang sama.

Posisi Matahari dipotret pada saat summer solstice, ekuinoks, dan winter solstice tanggal 21 Juni 2019, 23 September 2019, dan 22 Desember 2019. Kamera yang digunakan adalah kamera DSLR Canon EOS 600D dengan nilai eksposure dan ISO yang berbeda. Kamera diletakkan di posisi yang sama menggunakan tripod agar tidak berguncang saat memotret. Kamera diarahkan tepat ke arah Matahari terbit dan mengacu pada objek tertentu. Pada penelitian ini objek yang menjadi acuan adalah menara pemancar. Posisi Matahari dipotret pada waktu yang sama. Pada penelitian ini posisi Matahari dipotret setelah Matahari terbit yaitu pada pukul 07.00 WIB. Hasil potret pada tanggal-tanggal tersebut kemudian diolah dengan cara cropping dan skewing untuk menyamakan posisi sehingga menjadi satu gambar dengan mengacu pada objek acuan yaitu menara pemancar. Cropping dilakukan untuk memperoleh medan pandang dengan ukuran tertentu agar tiga gambar bisa digabungkan dengan latar belakang yang sama. Skewing dilakukan untuk menyamakan pemandangan latar belakang, sehingga latar belakang bisa dikatakan sama. Nilai azimut Matahari diperoleh menggunakan aplikasi Accurater Times. Selanjutnya dicari nilai ralat relatif azimut Matahari dengan menggunakan persamaan (1):

$$
\text { ralat relatif }=\frac{A z_{\text {eks }}-A z_{\text {teori }}}{A z_{\text {teori }}} \times 100 \%
$$

Penelitian ini membutuhkan beberapa peralatan yaitu:

1. Kamera, digunakan untuk memotret posisi Matahari

2. Tripod, digunakan untuk menahan kamera agar tidak berguncang saat memotret

3. Laptop, digunakan untuk mungumpulkan dan mengolah data

\section{Hasil Penelitian dan Pembahasan}

Posisi matahari pada saat summer solstice tanggal 21 Juni 2019 dapat dilihat pada gambar 4. Gambar diambil pada pukul 07.00 WIB. Kondisi langit pada saat pengambilan data cerah dengan sedikit berawan sehingga posisi matahari dapat terlihat dengan jelas. Pada saat summer solstice, Matahari berada pada titik terjauh di sebelah utara dari khatulistiwa. Dari gambar 4 dapat terlihat Matahari berada di sebelah kiri menara pemancar.

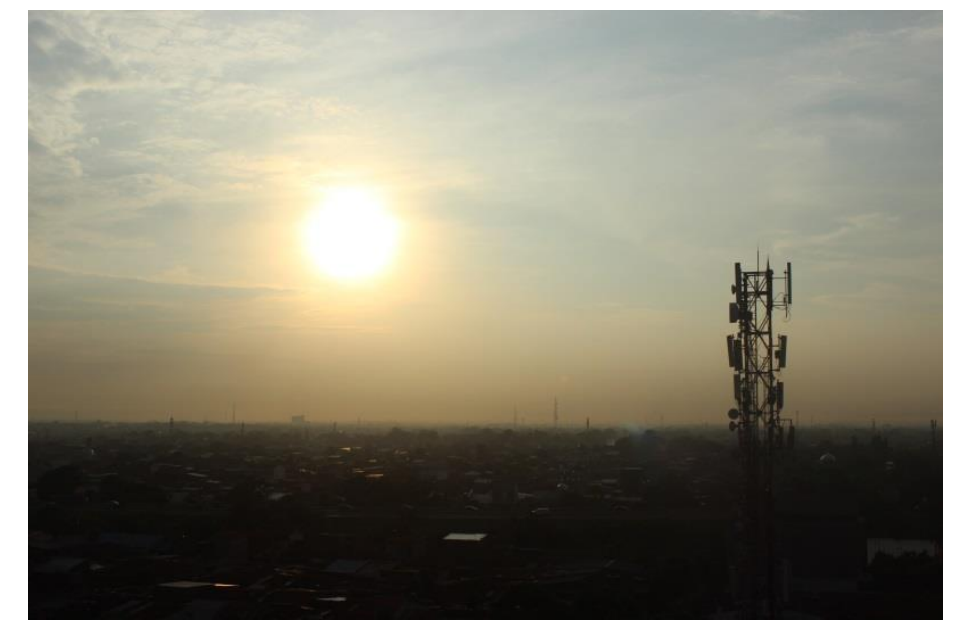

Gambar 4. Posisi Matahari tanggal 21 Juni 2019 pukul 07.00 WIB di OIF UMSU

Posisi matahari pada saat ekuinoks tanggal 23 September 2019 dapat dilihat pada gambar 5. Gambar diambil pada pukul 07.00 WIB. Pada saat ekuinoks, Matahari berada di khatulistiwa. Kondisi langit pada saat pengambilan data dipenuhi dengan kabut tebal. Meskipun ditutupi kabut yang tebal namun posisi Matahari masih dapat terlihat dengan jelas. Kabut hanya menutupi sebagian besar cahaya dari Matahari. Jika pada 

tanggal 21 Juni 2019 posisi Matahari terlihat berada di sebelah kiri menara pemancar, pada tanggal 23 September 2019 posisi Matahari berada sedikit di sebelah kanan menara pemancar.

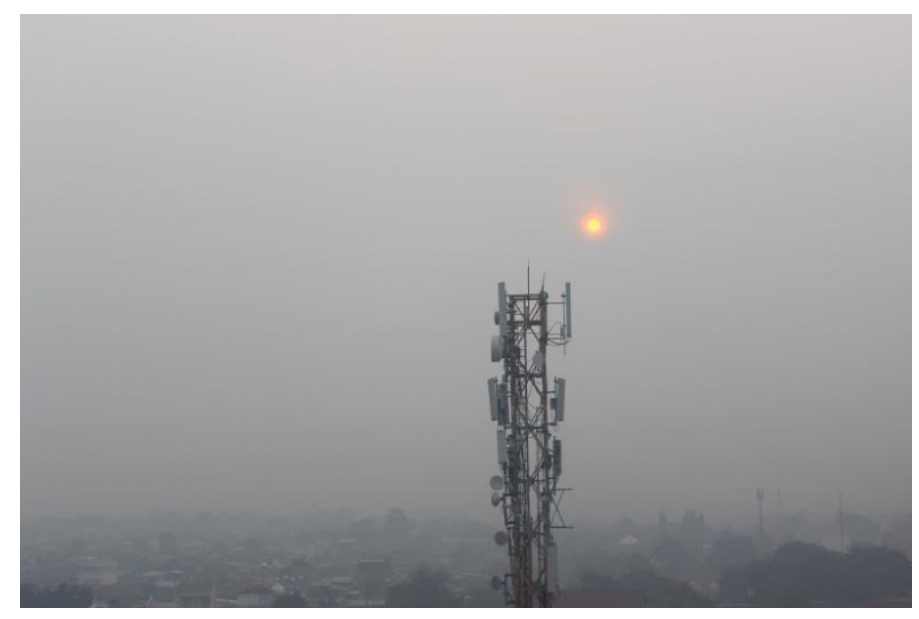

Gambar 5. Posisi Matahari tanggal 23 September 2019 pukul 07.00 WIB di OIF UMSU

Posisi Matahari pada saat ekuinoks tanggal 22 Desember 2019 dapat dilihat pada gambar 6. Gambar diambil pada pukul 07.00 WIB. Pada saat winter solstice, Matahari berada pada titik terjauh di sebelah selatan dari khatulistiwa. Kondisi langit pada saat pengambilan data ditutupi oleh awan sehingga posisi Matahari sulit dilihat. Meskipun posisi Matahari sulit dilihat, namun cahaya Matahari masih dapat terlihat diantara kumpulan awan. Cahaya Matahari yang paling terang terlihat berada di sebelah kanan menara pemancar. Jika pada tanggal 23 September 2019 posisi Matahari terlihat berada sedikit ke kanan menara pemancar, pada tanggal 22 Desember 2019 posisi Matahari dari menara pemancar semakin jauh ke kanan.

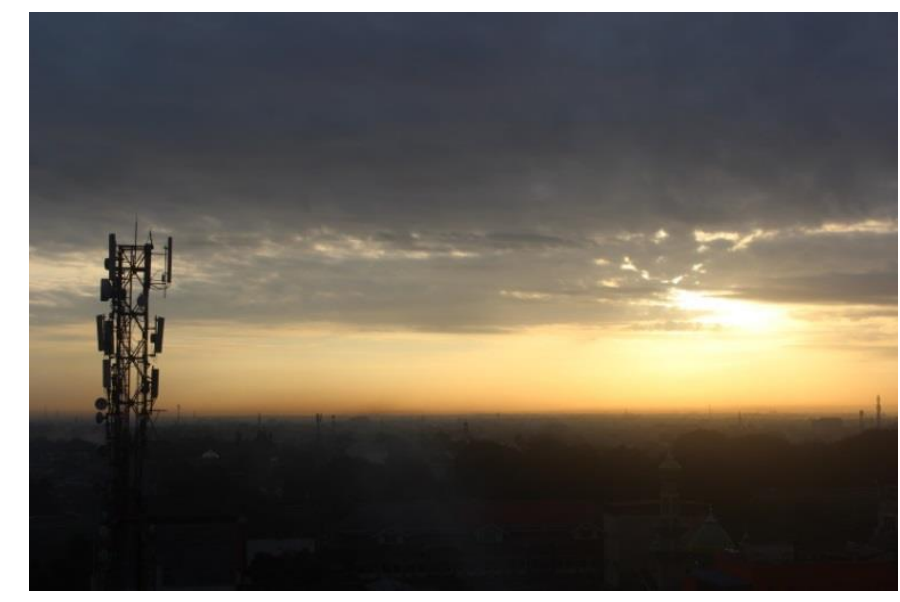

Gambar 6. Posisi Matahari tanggal 22 Desember 2019 pukul 07.00 WIB di OIF UMSU

Untuk membandingkan posisi Matahari saat summer solstice, ekuinoks, dan winter solstice, data yang berupa gambar digabungkan menjadi satu gambar. Penggabungan tiga gambar dilakukan sedemikian rupa sehingga menghasilkan sebuah gambar panorama seperti terlihat pada gambar 7 . Dikarenakan pada saat ekuinoks kondisi langit dipenuhi dengan kabut, sehingga gambar 7 terlihat seperti posisi Matahari yang berada di lokasi yang berbeda. 


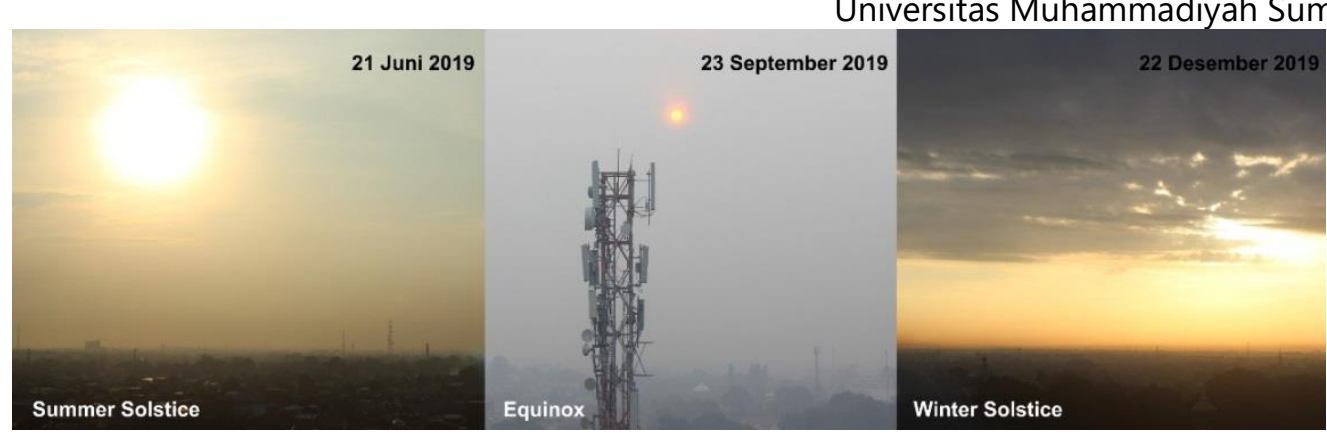

Gambar 7. Gabungan gambar posisi Matahari saat summer solstice, ekuinoks, dan winter solstice di OIF UMSU

Posisi Matahari pada saat ekuinoks terlihat lebih tinggi daripada saat summer soltice dan winter solstice. Pada saat ekuinoks, Matahari berada tepat di khatulistiwa sehingga nilai azimut Matahari berdasarkan teori sebesar $90^{\circ}$. Pada saat summer solstice, Matahari berada di $23,5^{\circ}$ LU sehingga nilai azimut Matahari berdasarkan teori sebesar $66^{\circ} 30^{\prime}$. Pada saat winter Solstice, Matahari berada di $23,5^{\circ} \mathrm{LS}$ sehingga nilai azimut Matahari berdasarkan teori sebesar $113^{\circ} 30^{\prime}$. Nilai azimut pada saat Matahari pada saat summer solstice, ekuinoks, dan winter solstice pukul 07.00 berdasarkan Accurate Times dapat dilihat pada tabel 1. Nilai azimut Matahari pada tanggal 21 Juni 2019 pukul 07.00 WIB tidak tepat $66^{\circ} 30^{\prime}$ melainkan $66^{\circ} 49^{\prime}$. Hal sama juga diperoleh pada tanggal 23 September 2019 dan 22 Desember 2019. Nilai azimut Matahari yang diperoleh dengan Accurate Times memiliki perbedaan yang kecil dibandingkan dengan nilai azimut Matahari berdasarkan teori dengan nilai ralat sebesar $\pm 1 \%$. Perbedaan ini desebabkan disebabkan lokasi pengambilan data berada di $3^{\circ} 34^{\prime}$ LU, sehingga Matahari tidak bergerak tegak lurus terhadap horizon melainkan miring dengan sudut sebesar $3^{\circ} 34^{\prime}$.

Tabel 1. Nilai azimut Matahari pada saat summer solstice, ekuinoks, dan winter solstice

\begin{tabular}{cllccc}
\hline No & \multicolumn{1}{c}{ Nama } & \multicolumn{1}{c}{ Tanggal } & $\begin{array}{c}\text { Azimut } \\
\text { (Teori) }\end{array}$ & $\begin{array}{c}\text { Azimut } \\
\text { (Accurate Times) }\end{array}$ & Ralat Relatif \\
\hline \hline 1 & Summer solstice & 21 Juni 2019 & $66^{\circ} 30^{\prime}$ & $66^{\circ} 49^{\prime}$ & $0,4 \%$ \\
2 & Ekuinoks & 23 September 2019 & $90^{\circ}$ & $90^{\circ} 50^{\prime}$ & $0,9 \%$ \\
3 & Winter sosltice & 22 Desember 2019 & $113^{\circ} 30^{\prime}$ & $114^{\circ} 50^{\prime}$ & $1,2 \%$ \\
\hline
\end{tabular}

\section{Kesimpulan}

Ungkapan Matahari terbit dan terbenam secara tidak langsung mengatakan bahwa Matahari bergerak naik ke atas horizon Bumi di arah timur kemudian turun ke bawah horizon Bumi di arah barat. Ungkapan tersebut tidak salah jika pengamat di Bumi yang menjadi acuan. Penentuan arah timur dan barat menggunakan Matahari terbit dan terbenam tidak dapat selalu dilakukan dikarenakan posisi Matahari yang selalu berubah sepanjang tahun. Matahari di Observatorium Ilmu Falak Universitas Muhammadiyah Sumatera Utara menunjukkan posisi yang berbeda saat ekuinoks, summer soltice, dan winter solstice. Matahari terbit di arah timur dan terbenam di arah barat hanya terjadi pada saat ekuinoks. Meskipun saat ekuinoks, namun Matahari tidak dapat menunjuk arah timur dan barat sepanjang hari. Hal ini disebabkan pergerakan Matahari tidak tegak lurus terhadap horizon melainkan miring sesuai dengan lintang tempat. Penelitian ini dapat dijadikan sebagai eksperimen sederhana bagi siswa sekolah dalam memahami fenomena astronomi sehari-hari.

\section{Kepustakaan}

[1] H. Rahmatiah, "Urgensi Pengaruh Rotasi dan Revolusi Bumi Terhadap Waktu Shalat," Elfalaky J. Ilmu Falak, vol. 1, no. 1, pp. 59-79, 2017.

[2] R. O. Mardiyanto, H. Widyantara, and I. Puspasari, "SunTracking pada Panel Surya untuk Optimalisasi Pengisian Catu Daya," J. Control Netw. Syst., vol. 4, no. 1, pp. 46-55, 2015.

[3] D. Agpianka and A. Mulwinda, "Virtualisasi Fenomena Rotasi Bumi dan Perbedaan Zona Waktu menggunakan Unity 3D," J. Tek. Elektro, vol. 7, no. 1, pp. 15-18, 2015. 
[4] M. Khusurur and J. Arifin, "Mengenal Equation of Time, Mean Time, Universal Time/Greenwich Mean Time dan Local Mean Time untuk Kepentingan Ibadah," YUDISIA, vol. 5, no. 1, pp. 123-138, 2014.

[5] T. Firdaus and A. R. Sinensis, "Perdebatan Paradigma Teori Revolusi: Matahari atau Bumi Sebagai Pusat Tata Surya?," Titian Ilmu J. Ilm. Multi Sci., vol. 9, no. 1, pp. 23-32, 2017.

[6] A. Y. Raisal, "Berbagai Konsep Hilal di Indonesia," Al-marshad J. Astron. Islam dan Ilmu-Ilmu Berkaitan, vol. 4, no. 2, pp. 146-155, 2018.

[7] D. Endang, Kosmografi. Yogyakarta: Ombak, 2014.

[8] N. Sopwan, "Citra matahari ektrim utara dan ekstrim selatan sebagai pembelajaran pergerakan matahari," Pros. Semin. Nas. Fis., no. Tabel 1, pp. 33-36, 2018.

[9] A. A. Rahman and M. Rivai, "Sistem Otomatisasi Pelacakan Objek Astronomi Menggunakan Teleskop Berdasarkan Stellarium," J. Tek. ITS, vol. 6, no. 2, pp. 521-526, 2017.

[10] P. Kurniawan, M. Rivai, and Tasripan, "Penentuan Arah Teleskop Digital Melalui Komunikasi Wi-fi," J. Tek. POMITS, vol. 2, no. 2, pp. 283-288, 2013.

[11] T. Fahmi, D. W. Khaidir, and M. Ali, "Optimasi Single Axis Tracking Untuk Solar Cell," Pros. Semin. Nas. Fortei Reg. 7, vol. 2, pp. 357-360, 2019.

[12] N. M. Pujani and N. K. Rapi, "Pelatihan Praktikum IPBA Bagi Guru SMP/SMA di Kota Singaraja Menuju Olimpiade Astronomi," Widya Laksana, vol. 2, no. 1, pp. 20-30, 2013.

[13] R. Elzulfiah, D. E. Mahanti, F. Ramadhan, and H. Nasbey, "Kajian Perkembangan Pendidikan Astronomi Untuk SMA di Indonesia," Pros. Semin. Nas. Fis., vol. 4, pp. 37-42, 2015. 